\title{
CONCEPTS AND IMAGES \\ OF THE FUTURE IN \\ RECENT GERMAN POETRY
}

\section{Reinhold Grimm ${ }^{1}$}

\begin{abstract}
German poetry has been obsessed with concepts and images of the future for decades. The present article concentrates on the pertinent contributions by the two leading German poets, Günter Kunert and Hans Magnus Enzensberger, and their lyrical output since the late 1980 s. What they portray is, on the whole, a rather gloomy picture, albeit not without a bit of redeemding irony.
\end{abstract}

\section{Concepts and Images of the Future in Recent German Poetry}

Of course, the fact that I cannot here treat the whole wealth of present-day German poetry (or poetry from the German-speaking countries, i.e., Germany with the inclusion of Austria and the respective part of Switzerland) ought to go without saying; this is plainly impossible for various and obvious reasons. I therefore decided to concentrate on the latest, the most recent collections of poems by the two lyricists who must still be seen as the foremost ones even though they have turned a sound seventy by now: namely, Hans Magnus Enzensberger and Günter Kunert, both of whom -the former from the outset, the latter since many years- have been living

\footnotetext{
${ }^{1}$ University of California -Riverside
}

and working in what once was called West Germany, or the Federal Republic of Germany (FRG) in the narrower sense. However, from East Germany, or the east while German Democratic Republic (GDR) too, weighty poetic voices relevant to our topic could be adduced; I merely mention the still leading poet there: namely, Volker Braun, who, after all, turned only sixty in 1999. There is, for example, a poem of his entitled "Desert Storm", which deals with the Gulf War, needless to say, but culminates in a pair of lines that are genuinely prognostic:

Saddam Hussein the troublesome supplier

Decorated with weaponry of his long-standing patrons

NEBUCHADNEZZAR from the colonial school

Pushed into the corner of the world

The North is telling the South what's what GOD

WITH US / THE MOTHER OF ALL BATTLES

The smolder of the hemispheres

Kindled with inexpensive oil And Baghdad my Dresden is fading away WITHOUT VIOLENCE fall's scrap heap of hope

The dead soldiers of the old century 
The phantom armies of the new one's Armageddon. ${ }^{2}$

In the German original, the concluding lines run as follows:

Die toten Soldaten des alten Jahrhunderts

Die Geisterheere im Endkampf des neuen. ${ }^{3}$

Evidently, I deviated from the exact rendition of "Endkampf" (literally, "final phase of the battle", or "final struggle") which would immediately suggest itself, choosing instead -with the tacit approval of the author, by the way- the term "Armageddon". Why? Because what Armageddon denotes in English is probably not just the place, time, and battle themselves of that apocalyptic finale which John (cf. Rev. 16:16) had prophesied, but also, secularized and most generally, "a vast decisive conflict or confrontation" (thus Webster). At first sight, granted, it appears as if Braun intended to conjure up the sole vision of a latter-day Battle of the Catalaunian Fields in France where in A.D. 451 the ghosts of the slain continued to fight in the sky according to the legend; on closer scrutiny, though, we realize that Braun clearly aimed at said biblical connection as well. Doubtless, he anticipates a both global and apocalyptic event in the near future, and its geographic implications (the North, or so-called First World, versus the

${ }^{2}$ Volker Braun, "Dessert Storm", Pembroke Magazine 26 (1994): 138. The translation is mine, as are all those following.

${ }^{3}$ Volker Braun, Texte in zeitlicher Folge, vol. 10 (Halle: Mittel-deutscher Verlag, 1993) 53.
South, or so-called Third World) are even more palpable than its religious ones (a fundamentalist and fanaticized Islam versus a shallow and, to a wide extent, rotten Christendom). Either relation can, hence must, be identified in Volker Braun's poem "Desert Storm". 4

Admittedly, there also exist, and in Braun's poetry in particular, prognostic verses that for the main part, or even exclusively, refer to Germany alone and her future; still, the vast majority of Kunert's and Enzensberger's futuristic concepts and / or images reveal themselves as all-embracing: that is, as referring not only to Germany but likewise to Europe and the Western World at large, indeed to the globe in its entirety. And how could it possibly be otherwise? How could one, nowadays more than ever, limit one's prospects for the future to a single country? Such, at any rate, is the basic insight that informs the pertinent lines, strophes, and poems from the six volumes of verse I examined and tried to investigate in that respect. They comprise three each by Kunert and by Enzensberger: to wit, Kunert's Berlin beizeiten ("Berlin Betimes") of 1987, his Fremd daheim ("A Stranger At Home") of 1990, and his Mein Golem ("My Golem") of 1996, on the one hand, and, on the other, Enzensberger's Zukunftsmusik ("Music [or Dreams] of the Future") of 1991 and his Kiosk: Neue Gedichte ("Newstand: New Poems") of 1995. (Regarding his third collection, Leichter als Luft: Moralische Gedichte ["Lighter than Air: Moral Poems"]

\footnotetext{
4 As to these and some other interpretative remarks, cf. Also Reinhold Grimm, "Around and after the Wende: Five Representative Poems" (forthcoming).
} 
of 1999, it came out in mid-August of that year, i.e., at a time when I had already completed the lecture version -in German- of this essay; nonetheless, I have now included, and shall discuss, whatever text from it seems important and enlightening enough for our purposes). While it must be manifest that the very title of the first volume of the Enzensbergerian triad, Zukunftsmusik, signals, or opens up, a prospect of the future, Kunert refrained from so programmatic and overall an announcement, contenting himself with the isolated if, all the same, no less unmistakable heading "Zukunftsperspektive" ("A Perspective into the Future") for merely one of his many poems. It is this rich though sometimes rather contradictory verse material that we have to take up, whether summarily or in detail, in the considerations following.

As indicated, Kunert for one does not offer an entire volume nor even -despite the promising title just quoted- an entire poem devoted to the description, or depiction, of the future; what he provides are, in most cases, simply conceptions thereof enclosed in one line or a couple of lines. In short, they are scattered remarks, statements, anticipations, or prognoses, nothing further. But let us proceed from the beginning. In the first of Kurnert's three volumes, the one dating from 1987, we find a rare and peculiar use of the concept of future: namely, a retrospective glance at a 'past future', as it were. For what is it we read in his poem "Stadtbahnstenogramme 3" ("Stadtbahn Shorthand Notes 3"-the Stadtbahn being, needless to say, Berlin's suburban train system)? This: "Another German Future / left the scene long ago $\ldots$ by trains / bound for Auschwitz". ${ }^{5}$ Clearly, the poet here evokes the lost future of those who were murdered in the extermination camps, and he is of course dead serious; on the other hand, though, he makes, quite sardonically, an implied mockery of the equally lost future of the Third Reich, allegedly destined to last a thousand years. Still, this is an exception in Kunert's oeuvre, since his concepts of a future -not so much its images or depictionsotherwise pertain, naturally enough, to the time that lies ahead of us, the world to come. And they prove to be somber, indeed abysmally pessimistic, almost throughout. For instance, in his poem "Lifting of the Eyes", with the telling parenthetic addition "(After Chernobyl)", Kunert speaks of "a future devoid of human beings" in the wake of an atomic catastrophe; similarly, in his poem "A Walk at Night", he observes that then the earth will be "absolutely waste and uninhabitable forever" (cf. Berlin 49 and 65 , resp.). Yet, such predictions notwithstanding, the poet has repeatedly voiced his basic mistrustfulness concerning like prognoses or prophecies, ironically confessing, as in his verse entitled "Lament", that he distrusts both any "view of the future" and any "staring at one's own navel": "Denn ich mißtrau / der Zukunfts-wie der Nabelschau" (Berlin 116). Which is to say that he believes as little in the validity of a prospect for the future as he does in that

${ }^{5}$ Günter Kunert, Berlin beizeiten: Gedichte (Munich / Vienna: Hanser, 1987) 40; henceforth quoted as Berlin + page number in the text. The same applies to Günter Kunert, Fremd daheim: Gedichte (Munich / Vienna: Hanser, 1990) and Mein Golem: Gedichte (Munich / Vienna: Hanser, 1996) quote as Fremd and Golem, respectively. 
of an exaggerated concern for oneself, i.e., of so-called narcissism.

In Kunert's second volume, the one published in 1990, we do encounter, at long last, that seemingly exhilarating poem which is expressly labeled as "Zukunftsperspektive". What, however, do we read in it? We read that the poet foresees a veritable "standstill of time" (Zeitstillstand); everything, he explains, will stagnate to the point of sheer "motionlessness"; and if indeed an aim of sorts might still be left, it will reveal itself, paradoxically, as the "anteroom to nothingness" (cf. Fremd 100). In a word, we have no future at all according to Kunert. Equally generalizing, he adds in "Across from the Dumping Ground": "[er] gebe...die Welt verloren," which I wouldn't hesitate to render, echoing Shakespeare, as "all the world, methinks, is lost" (cf. Fremd 36). Generalizations of this kind are, to repeat, typical not only of Kunert but of Enzensberger as well; either envisages his futuristic ruminations, even if prompted by some German experience, almost always in a global, a worldwide context. Incidentally, with the poem "Apocryphal Self-Portrait", the volume Fremd daheim returns to that odd combination of future and navel from Berlin beizeiten in that Kunert unambiguously states he is "weary of my own enigma / sick with a threatening future" (Fremd 76). As a matter of fact, he even declares that what we term "future" has been "without any guarantee" whatsoever since time immemorial, or he sadly concludes: "Yesterday we traveled / toward the future / only to arrive at none anymore" (cf. Fremd 113 and 85, resp.).

It stands to reason, I suppose, that under suchlike circumstances the once so beloved and boundlessly extolled idea of utopia, too, is no longer worth anything, Thus, in his "Faust III: Final Performance ", the poet curtly remarks with a parodistic reminiscence of Goethe: "Gray, my dear friend, / is all utopia" (Fremd 81 -whereas Goethe has, as is well known "theory"). And early on in Kunert's third volume, the one dating from 1996, the poem "Cosmology" reports that "utopia" is a "country behind the moon", and throughly turned into "karst" to boot (cf. Golem 14). Both poems convey the selfsame message: namely, the present, perhaps even permanent, uselessness of this idea, which has become "gray", i.e., colorless, faded, and dull, and / or "karst" (verkarstet), i.e., bleak, barren, and fruitless. Elsewhere in Mein Golem, Kunert again harks back to previous concepts and utterances of his, as when he foretells a total "Zeitstillstand": "After tempests and crashes of thunder / standstill of time will set in" (Golem 17). $\mathrm{He}$ anticipates, no question about it, a disaster or a series thereof -whether natural catastrophies or new world warswhich will eradicate all human time, leaving everything stagnant; and, once more, this devastating process proves to be one of global dimensions. Our planet needs must perish, Kunert assures us, "and I with it" (Golem 12). Nevertheless, his ultimate futuristic summary in Mein Golem's concluding cycle of elegies amounts to a surprising paradox, no matter how bitterly ironical it may sound: "A dim light illuminates the future everywhere" (Golem 77; my emphasis).

Paradoxical statements are surely not missing in Hans Magnus Enzensberger's contributions, either, and there also occur some other similarities in them. But one thing is decidedly different in his verse as opposed to Kunert's, who contents himself, as we said and saw, with isolated remarks scattered about in his volumes. 
Enzensberger, rather than forging concepts, creates images, and rather than jotting down an occasional pertinent line or couple of lines, he composes entire strophes and, indeed, poems devoted to the future. Hence, I shall quote and, whenever required, comment on a number of unabridged poetic texts of his as they can be gathered -almost at random, so to speak- from his three collections Zukunftsmusik of 1991, Kiosk of 1995, and Leichter als Luft of 1999.

Let us begin with a poem entitled "On Life after Death". It is the penultimate one in the second volume and reads as follows:

Afterwards, when the turbines have stopped,

The neon signs are extinguished,

When the first cracks appear in the concrete

and slowly, slowly branch out a pattern of hairlines, illegible; when winged creatures come whirring along,

bringing tiny capsules,

bringing seeds and spores from afar, when saxifrage bursts open the walls, ants swarm over split cables and the deserted switching stations are shielded by giant trees, then life is proliferating again: A peculiarly lofty spectacle, yet far and wide there is no PiranesiTo populate this Angkor Wat with shepherds and cavaliers. ${ }^{6}$

${ }^{6}$ Hans Magnus Enzensberger, Kiosk: Neue Gedichte (Frankfurt am Main: Suhrkamp, 1995) 128; henceforth quoted as Kiosk + page number in the text. The same applies to Hans Magnus Enzensberger, Zukunsmusik
No doubt, that which constitutes this poem is a twofold vision of the future: on the one hand, an undeniable dystopia insofar as the human race is concerned - on the other hand, in the realm of plants and animals, something that seems to be even a kind of utopia, as it were. After a global catastrophe (which is implied) life has started "proliferating again", we are told; however, it is, without fail, a life devoid of any human beings. The poet expresses this total absence by ironically informing us that no artist is around anymore who might be able "to populate" those overall shambles. Thus, the last threesome of verses forms a syncretistic evocation of human art which is irrevocably, irretrievably gone. Mention is made of the Italian painter and graphic artist Giambattista Piranesi from the $18^{\text {th }}$ century -a favorite of Enzensberger's, by the way- who produced the famous if wholly uncanny Carceri d' invenzione, or "Imaginary Dungeons"; and side by side with him, there emerge the perhaps even more famous temple ruins of Angkor Wat in Cambodia as well as (implicitly once more, yet clearly recognizable) familiar French rococo painters such as Watteau or Fragonard. All of which results, I venture to say, in a both striking and strangely accomplished image.

(Frankfurt am Main: Suhrkamp, 1991) and Leichter als Luft: Moralische Gedichte (Frankfurt am Main: Suhrkamp, 1999) quoted as Zukunsmisik and Luft, respectively. 
That animals and plants have the longer staying power and therefore will long outlive the human race, just as they have lived and thrived long before it: this insight and conviction permeates, at least in part, further Enzensbergerian poems. Take, for instance, the one which bears the charming heading "Ein Hase im Rechenzentrum" ("A Hare [or Rabbit] at the Computer Center"). It juxtaposes -or, if you prefer, opposes- that harmless little quadruped and the most sophisticated, most advanced technology, culminating in the sovereign and nearly serene stanza:

Out of the Eocene [58 million years ago] it hobbles past us into a future

rich in enemies

but nourishing and rank

like dandelion.

\section{(Zukunftsmusik 91f.)}

Even more so, according to the poem "Concerning the Question of Reincarnation", such virtually endless duration applies to the fly, our common housefly. Not only does it possess an immeasurable past, but it is also endowed with an immeasurable future. "[For] hundreds of millions of generations", the poet says, this fly has been the same, and it will remain the same, "absolutely unchanged", when "Nobody will be left / to describe it" (as Enzensberger brilliantly does) or "to shoo it away" (cf. Kiosk 84f.). And as if even that were not enough yet, the volume of 1999 contains a verse lapidarily titled "Equisetum". It needs no commentary:

As for the horsetail, the matter is this:

it, too, was actually bigger back then, couple hundred millions of years ago.

Devonian, Permian, Keuper glorious times indeed!

Later on, its delicate sprouts

helped my grandmother

in cleaning her dirty pots.

Nowadays it's no longer in use,

only its forebears, scraped from

the depths,

are still burnt up by us.

The horsetail ignores us,

Doesn't need us, discreetly propagates.

In the sloughy ditch it is biding its time,

Simpler than we are, and hence

unvanquishable.

Quietly, the gigantic future

is waiting for its gorgeous geometry.

(Luft 42)

So much for geological time, both future and past...

With my next example, I turn to historical time, indeed the present, if in a wider sense: namely, Germany's most recent decade after the so-called "Wende" of 1989 which brought about her reunification, and what this event has had and might still have in store for her people. The poem in question bears the title "Atmosphere of Departure"; however, since I can hardly expect every reader to know where the Potsdamer Platz is located, I added an explanatory subtitle that runs "(Berlin 1990)". Let me also mention that "Aufbruchsstimmung" (thus the original heading) is the only poem, whether by Enzensberger or by Kunert, to be devoted, solely and exclusively, to Germany and her situation: 
High above the suburbs gases, rosy illuminations, are fighting their silent battles. Under whisps of fleeting clouds concrete is crumbling, drenched with

champagne. At Potsdamer Platz the hobos, amid bottles of vermouth, ponder "the dual sense of being and of the awareness of being".

Objections tend to stay within limits here. Hosts of pilgrims populate the pedestrian zone in search of a new identity and of tropical fruits. The newcomers

let Valium-colored notes melt on their tongues.

On the left, too, on the second floor

departures are taking place:

Conscientiously, partners are at work

on the execution of a marriage. Contact lenses, stained with tears, in the luxurious smog. Duds sink into each other's arms.

The politburo: deserted and dead. Only the poet in his basement, by the light of a fifteen-watt bulb,

keeps poetizing as before for the sake

"of furthering humankind's selfrealization" Moved,

the wet eye begins to wander across the fresh partitions.

\section{(Zukunftsmusik 42f.)}

This complex poetic vignette, replete with audacious images and other rhetorical devices, ${ }^{7}$ admirably succeeds in depicting the hectic situation and mood that characterized Berlin after the Wall had come down and when, for weeks on end, the Easterners were pouring into the western part of the city in order to shop there in the most unrestrained manner. Unfortunately, I cannot discuss these verses in any detail; I have to restrict myself to the poem's concluding sentence, indeed to its last two words. For it is with them that Enzensberger puts forth his prognosis concerning the fate of a unified Germany. His technical term "frische Sichtblenden" does not denote, as has been surmised, "fresh blinds" but, as I have rendered it, "fresh partitions" (erected, in all likelihood, round some of Berlin's many building sites). In point of fact, "Sichtblenden" may even be translated, according to the authoritative German dictionary, Duden, as "dividing walls" (Trennwände)! Hence, not only does Enzensberger here most consummately, and with gallows humor to boot, recreate and convey that specific "atmosphere of departure", but he also arrives at an ominous foreboding and presentiment, perhaps even prediction, of scores of new

${ }^{7}$ For example, a veritable conceit can be gleaned from the "Valium-colored notes" that the "newcomers" from the East let "melt on their tongues". Valiumfarben doesn't exist in German, as little as does its equivalent in English; it is a neologism in either language. But Valium is the trademark of a well-known tranquilizer used to relieve anxiety and tension, and the "notes" (Scheine) are of course the banknotes which had been distributed to the Easterners by the government. As for their melting in the pilgrims' mouths, it must be obvious that Enzensberger, boldly and almost blasphemously, compares their soothing effect to that of the consecrated wafers received by the faithful. 
separations precisely after, nay as a result of, Germany's reunification. And hasn't this message of his -veiled and merely intimated, it is true, yet unmistakable nonetheless- proved to be entirely correct? Furthermore, let me confess in passing and due modesty that I myself, having experienced Berlin in the fall of 1990, gained very similar insights and publicly proffered them, about half a year later, when I had to introduce a panel discussion with the late German Chancellor Willy Brandt, who had been invited to Riverside. $^{8}$

"Altes Europa": such is the title of another historical or political poem composed by Hans Magnus Enzensberger, and ironically extending, though merely by intimation again, into the future -albeit one that is, evidently, no longer that of present-day Germany alone. Indulging for my part in a bit of irony, I rendered its title as "Good Old Europe":

In the warm aroma of bread by the bakery, under its shop sign with the golden pretzel, a stout magician from Guinea is offering key rings for sale in Grayfriars Lane. (Who were the Gray Friars?)

Runty, wiry drug dealers with giant sneakers are quarrelingsnarling in the language that nobody understands -by the wall of Holy Ghost Churchyard. (Who was the Holy Ghost?)

${ }^{8}$ My introduction was subsequently printed, under the title "The Travails of the Plains: On Some Consequences of German Unification", in German Studies Review 15 (1992): 87-98.

\author{
And then that old woman from \\ Bosnia, \\ who, for a couple of minutes, \\ stretches out her stiff leg on a \\ bench \\ in the dark green, quiet courtyard \\ behind the dark green portal \\ of Elephant Inn, built in 1693.
}

\section{(Kiosk 17)}

What this second historico-political poem envisages, even if couched in the present tense, amounts, I am tempted to infer, to a near utopian projection. For it appears to portray -with a definitely German flavor, granted, but an overall European touch as well- the accomplished integration of foreigners and refugees in the societies of the old continent; thus, its title and text seem to impart a positive, somewhat optimistic message of sorts. All the same, Europe, her gradual waning notwithstanding, has preserved an awareness of her double-edged past and heritage, the year 1693 revealing itself as particularly meaningful. Namely, wasn't the $17^{\text {th }}$ century, on the one hand, the age of European Baroque in art and music, of classical French literature, the Spanish Siglo de Oro, etc., while, on the other hand, the poet's explicit date points to the Thirty Years' War, the most devastating one in German history, and simultaneously reminds us of the year 1939, the outbreak, exactly three centuries afterwards, of the Second World War, which was hardly less disastrous and destructive? Small wonder, therefore, that Enzensberger's programmatic jumbo essay complementing his verse, "The Great Migration" of 1992, should come up with a far less promising view and result. In spite of his poem's good tidings, he cannot help drawing the black conclusion: 
The goal of integration has not yet been accepted by large parts of the European population. The majority is not ready for it, at present perhaps not even capable of it. ${ }^{9}$

As happens so often, the sober approach of discursive prose belies the wishful, no matter how indirect and concealed, visions and hopes of poetry.

The following two texts, once more in the present tense yet evoking the future and, to a certain degree, the past as well, unfold a comprehensive poetic picture of the phenomenon of war, both of its causes and it half hidden, half overt manifestations. Titled "War, Like", the first of them constitutes an impressive attempt at defining, by way of ten elaborate or laconic similes, the quintessence of what Enzensberger has labeled as "global civil war" (Weltbürgerkrieg) already in "The

9 Hans Magnus Enzensberger, Civil Wars: From L.A. to Bosnia, trans. Piers Spence and Martin Chalmers (New York: The New Press, 1994) 137. For a detailed interpretation of the poem, see Reinhold Grimm, "Wanderungen...ob aber auch Wandlungen? Enzensbergers Altes Europa", first published in Études germanoafricanes [Dakar, Senegal] 14 (1996): 50-55; slightly abridged or revised versions were printed in Gedichte und Interpretationen, vol. 7: Gegenwart II, ed. Walter Hinck (Stuttgart: Reclam, 1997) 46-54 and in Der Zorn altert, die Ironie ist unsterblich: Über Hans Magnus Enzensberger, ed. Rainer Wieland (Frankfurt am Main: Suhrkamp, 1999) 69-75.
Great Migration"; ${ }^{10}$ still, the jumbo essay accompanying so to speak, and implicitly discussing this remarkable text is the one of 1993, "Prospects of Civil War". And just as "prospect" here must be read as an ambiguity meaning "outlook" as well as "foretaste", so, too, must the lines and imagery of the poem. No discrepancy between prose and verse can be perceived in the case of "War, Like", either in this regard or in any other. Hence, what is it Enzensberger has to tell us about that modern civil war which he claims is raging worldwide, in the big cities with their gangs and skinheads and in the remotest African bush? "It", he says,

glitters like the smashed beer bottle in the sun

at the bus stop in front of the nursing home

It rustles like the ghostwriter's manuscript

at the peace conference

It flickers like the bluish reflection of the TV screen

on the somnambulistic faces

It smells like the steel of the fitness studio's machines

like the breath of the bodyguard at the airport

It bells like the speech of the chairman

It swells like the fatwah out of the mouth of the ayatollah

It chirps like the video game on the schoolboy's diskette

It glints like the chip at the bank's computing center

${ }^{10} \mathrm{Cf}$. Hans Magnus Enzensberger, Die Große Wanderung: Dreiunddreißig Markierungen. Mit einer Fußnote 'Über einige Besonderheiten bei der Menschenjagd' (Frankfurt am Main: Suhrkamp, 1992) 47. 
It spreads like the puddle behind the slaughterhouse

Breathing

rustling

it swells

smells

like

(Kiosk 8f.)

As for the second of these two war poems, it proves at least as global and general as the first. In addition, though, its title, like that of the essay mentioned above, reveals itself as deliberately ambiguous, since the German word "Kriegserklärung" must be understood here as designating not only "Declaration of War" but also, beyond doubt, indeed primarily, "Explanation of War" "The whole poem thus forms, in rapid succession, one huge and uninterrupted enumeration of bellicose conditions and causes:

In the back room of the beer cellar.

where seven drunks have congregated,

it starts, the war; it's smoldering

at the nursery school; it's being plotted

by the Academy of Sciences; no,

it's thriving in a delivery room

of Gori or Braunau, in the internet,

at the mosque; it's being oozed out

by the narrow mind of the patriotic poet;

11 Compare already Volker Branus "Kriegserklärung" of 1966, which emphasizes this ambiguity even typographically; in Braun, Texte in zeitlicher Folge, vol. 2 (Halle / Leipzig: Mitteldeutscher Verlag, 1990) $105 \mathrm{ff}$. since someone has taken offense, since someone

has tasted blood, in the name of God:

that's why war rages, for reasons of color,

in bunkers, for kicks, or simply by accident;

since sacrifices have to be made

for humankind's salvation, at night

in particular, because of the oil fields;

also, since self-mutilation, too, is enticing

and since the money is flowing

profusely: that's why

it starts, the war, in a state of delirium;

because of the soccer match that was lost;

far from it, for Heaven's sake; alright then;

though no one has wanted it; aha; just so, for pleasure, heroically, and since we can't think of anything better.

\section{(Luft 8f.)}

Here, alongside present and future, also the past looms large: to wit, in that the poet refers to Hitler and the Nazis (through the place-name "Braunau", but likewise through the "seven drunks" in a "[Munich] beer cellar)" as well as hinting at Stalin (through the place-name "Gori" in Caucasian Georgia) and, needless to say, at the Gulf War (through the unequivocal "oil fields"). And there is, of course, more yet that could be listed. As before, however, the futuristic aspects tend to outweigh all others because, as Enzensberger informs us in no uncertain terms; both novel civil wars and conventional ones -shall we call them 'normal' or 
'regular'?- will most probably be on the increase rather than on the decrease in the years and decades to come. ${ }^{12}$ Nor does the poet exclude altogether, I trust, either old-fashioned hostilities between independent nations and states or even atomic warfare.

Regrettably, the concluding title poem of Enzensberger's volume of 1991, "Zukunftsmusik", defies each and every attempt at providing an adequate, i.e., poetically satisfactory, English rendition, for it is virtually swarming with difficult idioms, with puns or double entendres, and with rhetorical devices such as series of anaphora or the inimitable figura etymologica. Thus, I must leave this enlightening poem untranstlated, confining myself, willy-nilly to summarizing the mere gist thereof. Its very title, by the way, had once been coined as a polemical slogan against Richard Wagner's then avant-garde music; but what it signifies nowadays is something the realization of which, if any, lies still in faraway future, that is, something not joy- and hopefully but most doubtfully utopian. In a word, Enzensberger, not unlike Kunert, denies the existence of a genuine future, or genuinely futuristic prospects, to put it more eloquently. Thinking and reasoning about that which might be in store for us is, he feels, highly uncertain at best: the future isn't waiting for us, isn't coming up or back to us, doesn't belong to us or care for us, won't have anything to do with us; and so on and so forth. The poem ends in a fivefold negation which I cannot but quote in the original:

${ }^{12}$ See Hans Magnus Enzensberger, Aussichten auf den Bürgerkrieg (Frankfurt am Main: Suhrkamp, 1993) 12.
War nicht [namely, said future], ist nicht für uns da, ist nie dagewesen, ist nie da, ist nie.

\section{(Zukunftsmusik 115)}

A future worthy of its name, Enzensberger insinuates, has never really been nor will ever really be.

And yet, his attitude, again not unlike Kunert's, is profoundly contradictory all the same. From a pithy poem entitled "Flight of Ideas", for instance, and also included in the volume Zukunftsmusik, we learn that, "for the time being, things still work, / indeed work well /, run their everyday course"; as a matter of fact, this poem blithely assures us that even "the end of the world / is perhaps / merely a temporary solution, or expedient [ein Provisorium]" (cf. Zukunftsmusik 80f.). Words that are exceedingly ironical, to say the least! I therefore believe it to be only fitting to conclude with the equally ironical "Optimistic Ditty" Enzensberger penned and published in 1999. Constituting the opening verse in this his third volume, it reads:

It does happen, now and then, That somebody cries for help. At once, someone else plunges into The water, completely free. In the thick of fattest capitalism, The glinting fire truck turns the corner And quenches the flames, or silver shines

From the beggar's hat all of a sudden.

Every morning the streets are teeming 
With people who run to and fro, without

Drawn knives, just at their leisure, In search of milk and radishes.

As in the midst of peace.

A glorious spectacle.

\section{(Luft 7)}

Sometimes at any rate, even as late as the turn of the millennium, it seems as if everything were "in the midst of peace" (im tiefsten Frieden). However, what will come next, in the course of the $21^{\text {st }}$ century?

\section{Manusya : Journal of Humanities}

$$
\text { Vol.2 No.2 (September 1999) }
$$

Vorasan Buranakarn

Philosophical Issues of Recycling

\section{Jaralvilai Charunrochana}

The Influence of Grammatical Gender on Hindi and German Speaker's Sex Categorization

\section{Pornrat Damrhung}

Cultivating the Garden of Theater Culture:

A New View on Traditional Theater in Thailand

Ronald W. Langacker

Correspondences, Compositionality, and Grammar

\section{Santirak Prasertsuk}

The House and the Reversible Destiny:

The Work of Arakawa and Madeline Gins

Somparn Promta

Buddhism and Science in Thai Society

Khaisang Sukhavadhana

The Thai Garden

\section{** ALL BACK ISSUES ARE STILL AVAILABLE **}

